\title{
STRATEGI PEMBELAJARAN PAI ANTI RADIKALISME DI SMP NEGERI 1 NGORO JOMBANG
}

\author{
Moch. Sya'roni Hasan ${ }^{1)}$ Nurul Chumaidah ${ }^{2)}$ \\ ${ }^{1,2)}$ STIT Al-Urwatul Wutsqo Jombang \\ ronistit@yahoo.com
}

\begin{abstract}
ABSTRAK
Radikalisme merupakan suatu paham yang sangat berbahaya jika berkembang dikalangan remaja. Oleh karena itu dalam mencegah bahaya radikalisme ini tidak cukup jika hanya menggunakan jalur hukum, polisi, dan pemerintahan saja, akan tetapi juga perlu melibatkan dunia pendidikan. Pendidikan disini yang dimaksud adalah pendidikan di sekolah formal, mengapa demikian, karena pendidikan formal merupakan pendidikan yang dilaksanakan dengan cara yang teratur, konsisten, sistematis, direncanakan, dan mempunyai jenjang sehingga lebih terarah. Berangkat dari kasus tersebut peneliti berkesempatan untuk mengadakan penelitian di SMP Negeri 1 Ngoro. Penelitian ini menggunakan pendekatan kualitatif dengan jenis penelitian studi kasus. Metode pengumpulan data dilakukan melalui wawancara, observasi dan dokumentasi. Teknik analisis data yang digunakan adalah reduksi data, data display dan verifikasi. Hasil penelitian adalah: (1) langkah-langkah pembelajaran PAI dalam mencegah radikalisme di mulai dengan (a) Pendahuluan, salam, berdoa dan mengulang dengan singkat materi yang kemarin, (b) Penyampaian materi baru kemudian anak diuji satu per satu di hadapan guru (c) Pembelajaran ditutup dengan do'a dan pemberian motivasi ataupun kuis-kuis kepada siswa. (2) strategi pembelajaran PAI dalam mencegah radikalisme dilakukan dengan dua cara: (a) dilakukan pembelajara PAI didalam kelas. (b) pembelajaran dalam mencegah radikalisme diluar kelas yaitu melalui pendekatan kepada siswa, melakukan pembiasaan-pembiasaan yang dapat membentuk pribadi siswa, membuat kelas khusus diluar jam sekolah untuk menjelaskan bahaya radikalisme, melakukan acara-acara keagamaan salah satunya dengan upacara peringatan hari santri, peringatan isro' mi'roj, dan juga membuat buku pribadi siswa yang berisi tentang tata tertib sekolah dan juga point-point pelanggaran yang dilakukan oleh siswa.
\end{abstract}

Kata Kunci: Strategi pembelajaran, Pembelajaran PAI, Anti Radikalisme 
Radicalism is a very dangerous notion, if it develops among teenagers. Therefore, in preventing the danger of radicalism, it is not enough if it uses legal way, the police and the government, but also need to involve formal education, because formal education is carried out in an orderly, consistent, systematic, planned, and has a level, so that it is more directed. Departing from this case, the researcher had the opportunity to conduct research at SMPN 1 Ngoro. This study used a qualitative approach to the type of case study research. Data collection methods were done through interviews, observation and documentation. Data analysis techniques used were data reduction, data display and verification. The results of the study were: (1) PAI learning steps in preventing radicalism was started with (a) Introduction, greeting, praying and repeating the material before, (b) Submission of new material, then the students were tested one by one by the teacher (c) Learning closed with prayer and given motivation or quizzes to students. (2) PAI learning strategies in preventing radicalism were carried out in two ways: (a) PAI learning was carried out in the classroom. (b) learning in preventing radicalism outside the classroom, those were through approached to students, made habituation that could shape students' personalities, made special classes outside school hours to explain the dangers of radicalism, conducted religious events, one of which was with the "santri day" memorial, commemoration isro 'mi'roj, and also made a student's personal book that contained school rules and also points of violations committed by students.

Keyword: Learning Strategies, Islamic education, anti-radicalism.

\section{PENDAHULUAN}

Menurut Fauzi Nurdin, paham radikalisme tidak sesuai dengan ajaran Islam karena cara-cara yang digunakan bersifat revolusioner, artinya membalikkan nilai kebaikan yang ada secara drastis dengan kekerasan serta diikuti aksi-aksi yang ekstrim. Akan tetapi apa yang dilakukan ini diatas namakan rakyat dan untuk rakyat dengan tujuan agar apa yang disampaikan dan dilakukan dapat diterima oleh masyarakat. ${ }^{1}$

Menurut Desmita, aksi-aksi ekstrim ini sering dilakukan oleh para remaja. Misalnya tawuran antar pelajar, tawuran antar geng motor, dan baru-baru ini yang terjadi pada kasus Audrey. Semua ini terjadi karena masa remaja merupakan masa dimana emosi mereka masih sangat labil, dan dimasa inilah mereka cenderung lebih mudah dipengaruhi pemikirannya dalam berbagai hal, dan mereka langsung mempercayainya tanpa menyikapinya secara kritis. ${ }^{2}$ Oleh karena itulah masa remaja

\footnotetext{
${ }^{1}$ A. Fauzi Nurdin, Islam dan Perubahan Sosial (Semarang: Reality Press, 2005), 16.

${ }^{2}$ Desmita, Psikologi Perkembangan Peserta Didik : Panduan Bagi Orang Tua dan Guru dalam Memahami Psikologi Anak Usia SD,SMP, SMA (Bandung: Rosda, 2009), 37.
} 
sering kali menjadi sasaran dalam penyebaran radikalisme, tidak hanya remaja saja yang menjadi sasaran mereka, bahkan tidak jarang anak dibawah umur pun menjadi target dalam penyebaran radikalisme.

Radikalisme ini merupakan suatu paham yang sangat berbahaya jika berkembang dikalangan remaja. Oleh karena itu dalam menangkal bahaya radikalisme ini tidak cukup jika hanya menggunakan jalur hukum, polisi, dan pemerintahan saja, akan tetapi juga perlu melibatkan dunia pendidikan. Pendidikan disini yang dimaksud adalah pendidikan di sekolah formal, mengapa demikian, karena pendidikan formal merupakan pendidikan yang dilaksanakan dengan cara yang teratur, konsisten, sistematis, direncanakan, dan mempunyai jenjang sehingga lebih terarah. ${ }^{3}$

Pendidikan formal yang lebih cocok disini adalah dalam materi pendidikan agama Islam. Mengapa demikian, karena pendidikan agama Islam dijadikan sebagai model pendidikan yang mengajarkan dan menanamkan ideologi yang memahami, menghormati, dan menghargai harkat dan martabat manusia tanpa membedabedakan antara manusia yang satu dengan manusia yang lainnya, tanpa melihat status sosial mereka, tanpa melihat apakah mereka kaya ataupun miskin. Dengan demikian, akan terjalin sikap saling mendengar, menghormati, dan menghargai pendapat untuk menemukan jalan terbaik dalam mengatasi berbagai macam problema yang dihadapi. ${ }^{4}$

Peranan seorang guru sangat penting dalam menangkal radikalisme, terutama seorang guru PAI, karena guru PAI dapat memberikan pemahaman tentang aqidah Islam secara benar dengan tidak mengesampingkan nilai-nilai kebhinekaan dan kebangsaan sebagai bekal untuk mencegah terjadinya konflik antar umat Islam atau antar umat beragama, dengan kata lain guru PAI diibaratkan sebagai dokter dan pendidikan agama Islam sebagai obatnya sedangkan lingkungan sekolah sebagai salah satu rumah sakitnya. ${ }^{5}$ Dan pendidikan agama Islam seperti inlah diharapkan dapat menangkal radikalisme pada kalangan remaja di lingkungan sekolah. Selain itu juga perlu dukungan dari orang tua dalam proses menangkal radikalisme dilingkungan rumah dintaranya adalah orang tua mengawasi pergaulan anaknya dirumah, dengan siapa anaknya berteman dan dengan siapa anakanya bergaul, dan memastikan juga apakah setiap hari anaknya benar-benar pergi ke sekolah atau tidak, dan jika ada sesuatu yang janggal dengan anaknya maka segera konfirmasi

3 Qurrotul Aniyah dan Moch. Sya'roni Hasan, Kehidupan Pluralisme Dan Penangkalan Radikalisme (Studi Kasus Di Pondok Pesantren Al - Urwatul Wutsqo Jombang) Proceedings: International Conference on "Islam Nusantara, National Integrity, and World Peace" 2018), 329.

${ }^{4}$ Moch. Sya'roni Hasan, Internalisasi Nilai Toleransi Beragama Di Masyarakat (Sidoarjo: Kanaka Media, 2019), 42.

${ }^{5}$ Z. Aqib, Profesionalisme Dalam Pembelajaran (Surabaya: Cendekiawan, 2002), 22. 
dengan pihak sekolah. Dengan demikian akan seimbang antara pengawasan disekolah dan dirumah.

Alasan lain yang mendorong peneliti untuk memilih judul ini dan memilih lokasi di SMP Negeri 1 Ngoro ini adalah karena satu tahun yang lalu di desa peneliti telah terjadi penangkapan 3 orang yang di duga anggota terorisme yang di lakukan oleh Densus 88 tepatnya pada bulan puasa. Lalu apa hubungannya ini dengan SMP Negeri 1 Ngoro?, hubungannya adalah karena remaja di desa peneliti rata-rata sekolah di SMP Negeri 1 Ngoro. Nah berangkat dari permasalahan ini maka peneliti ingin mengetahui bagaimana atau cara apa yang dilakukan di SMP Negeri 1 Ngoro ini untuk menangkal bahaya radikalisme agar jangan sampai terjadi hal yang serupa.

\section{METODE PENELITIAN}

Penulisan ini bertujuan: (1) mendiskripsikan langkah-langkah pembelajaran PAI dalam mencegah radikalisme di SMP Negeri 1 Ngoro. (2) untuk mengetahui strategi pembelajaran PAI dalam mencegah radikalisme. Penelitian ini menggunakan pendekatan kualitatif dengan jenis penelitian studi kasus. Metode pengumpulan data dilakukan melalui wawancara, observasi dan dokumentasi. ${ }^{6}$ Teknik analisis data yang digunakan adalah reduksi data, data display dan verifikasi. Sedangkan untuk mengecek keabsahan data meliputi perpanjangan pengamatan, ketekunan penelitian dan trianggulasi. ${ }^{7}$ Selanjutnya Instrumen Penelitian meliputi wawancara dan observasi dijelaskan seperti dalam tabel di bawah ini:

\begin{tabular}{|c|c|c|c|}
\hline No & $\begin{array}{c}\text { Jenis } \\
\text { Instrumen }\end{array}$ & Informan & Pertanyaan \\
\hline 1 & Wawancara & Guru & $\begin{array}{l}\text { a. Bagaimana langkah-langkah } \\
\text { pembelajaran PAI yang dilakukan di } \\
\text { SMP Negeri 1 Ngoro? } \\
\text { b. Bagaimana strategi pembelajaran } \\
\text { yang dilakukan di SMP Negeri } 1 \\
\text { Ngoro? } \\
\text { c. Metode apa saja yang digunakan guru } \\
\text { PAI dalam proses pembelajaran? } \\
\text { d. Apakah di SMP Negeri } 1 \text { Ngoro ini } \\
\text { ada indikasi yang mengarah pada } \\
\text { radikalisme? } \\
\text { e. Apa yang dilakukan guru PAI untuk } \\
\text { menangkal radikalisme? }\end{array}$ \\
\hline
\end{tabular}

\footnotetext{
${ }^{6}$ Emzir, Metodologi Penelitian Kualitatif Analisis Data (Jakarta: RajaGrafindo Persada, 2014), 37.

${ }^{7}$ Sugiyono. Metode Penelitian Pendidikan (Pendekatan Kuantitatif, Kualitatif, dan R\&D), (Bandung: Alfabeta. 2013),
} 


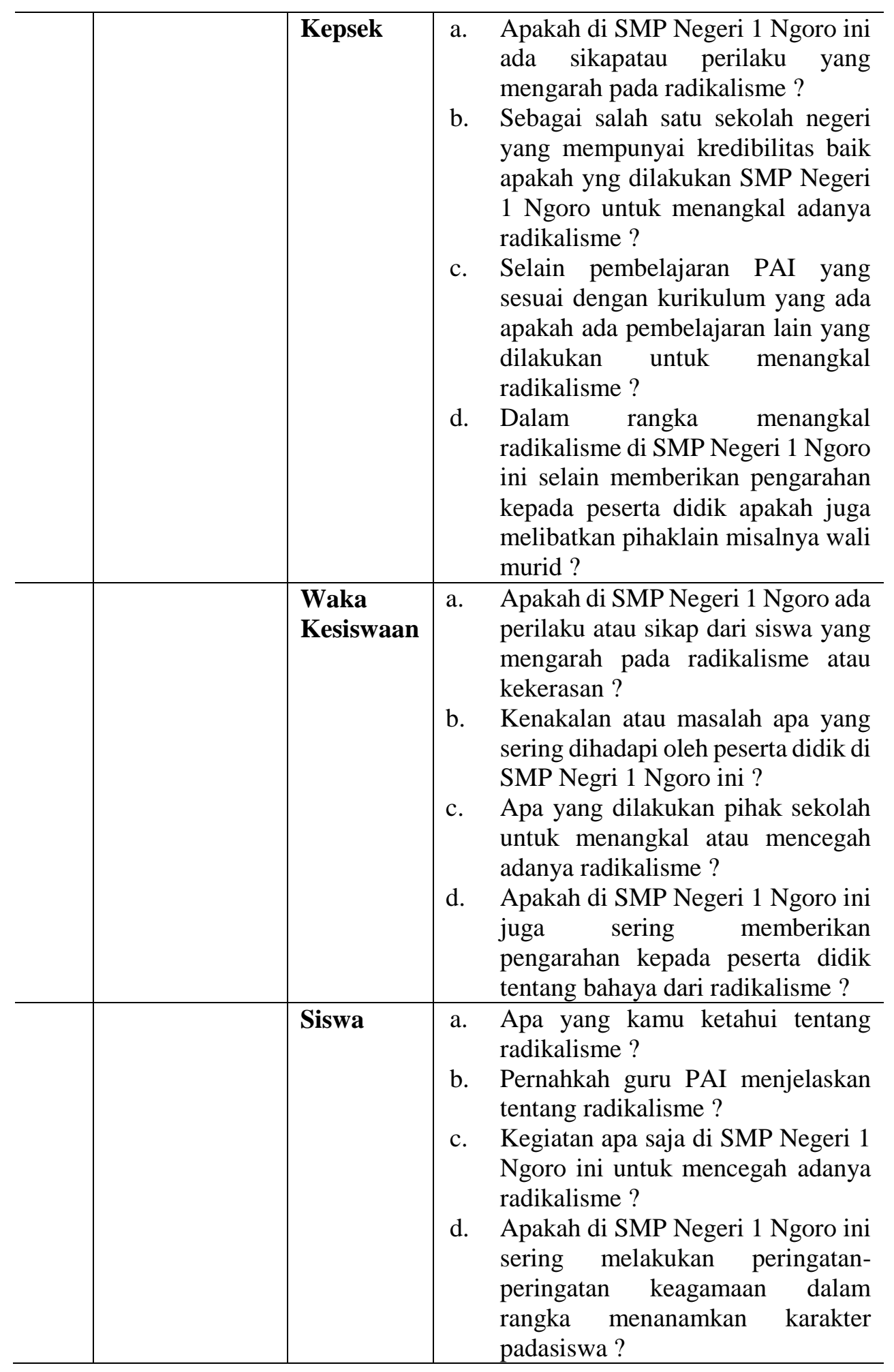




\begin{tabular}{l|l|l|lr}
\hline 2 & Observasi & a. & $\begin{array}{l}\text { Mengamati proses pembelajaran } \\
\text { PAI di SMP Negeri 1 Ngoro } \\
\end{array}$ & b. \\
& & $\begin{array}{l}\text { Mengamati kegiatan } \\
\text { ekstrakulikuler maupun kegiatan } \\
\text { pembiasaan yang ada di SMP } \\
\text { Negeri 1 Ngoro }\end{array}$ \\
\hline
\end{tabular}

\section{HASIL DAN PEMBAHASAN}

\section{A. Hasil Penelitian}

Berdasarkan penelitian yang dilakukan oleh peneliti, maka diperoleh data tentang implementasi pembelajaran PAI dalam mencegah radikalisme di SMP Negeri 1 Ngoro. Dalam penelitian ini peneliti menggunakan metode wawancara, observasi dan dokumentasi dalam mengumpulkan data. Wawancara dilakukan kepada guru PAI, wakil kepala sekolah, waka kesiswaan, murid, dan juga wali murid yang menjadi subjek penelitian. Selain itu peneliti juga melakukan pengamatan secara langsung dalam proses pembelajaran PAI tersebut, sekaligus di dukung dengan dokumentasi untuk memperkuat keabsahan data yang di peroleh.

Menurut hasil dari wawancara yang dilakukan di SMP Negeri 1 Ngoro mengenai implementasi pembelajaran PAI dalam mencegah radikalisme, sekaligus hasil dari observasi atau pengamatan yang dilakukan secara langsung oleh peneliti bahwa pembelajaran PAI di SMP Negeri 1 Ngoro ini selain dilakukan pembelajaran PAI pada umumnya, juga dilakukan pembelajaran diluar kelas yang memberikan pemahaman tentang bahaya dari radikalisme.

Diantara data-data yang diperoleh oleh peneliti ketika melakukan pengamatan di SMP Negeri 1 Ngoro tentang implementasi pembelajaran PAI dalam menangkal radikalisme adalah sebagai berikut :

\section{Langkah-langkah pembelajaran PAI Dalam Mencegah Radikalisme}

Pembelajaran adalah proses interaksi peserta didik dengan guru dan sumber belajar pada suatu lingkungan belajar. Pembelajaran PAI merupakan pendidikan dasar dalam menerapkan nilai-nilai keislaman. Seperti dalam berperilaku, beribadah, dan bersosialisasi. Radikalisme merupakan suatu paham yang secara berfikir dan bertindak cenderung bersikap kasar, keras, dan suka menebar ancaman kepada orang lain yang dianggap tidak sependapat dengannya. Oleh karena itu dalam penanganannya pun juga harus serius, salah satu cara yang dilakukan adalah melalui pembelajaran PAI.

Pembelajaran ini tentunya membutuhkan langkah-langkah yang tepat untuk mencapai tujuan yang diinginkan. Lsangkah-langkah pembelajaran PAI dalam mencegah radikalisme ini dilakukan berbagai cara dan antara 
guru yang satu dengan guru yang lain berbeda-beda sesuai dengan tujuan, media, metode dan evaluasi yang dilakukan oleh masing-masing guru. Berdasarkan hasil dari wawancara dan observasi secara langsung yang dilakukan di SMP Negeri 1 Ngoro ini maka diperoleh data tentang langkahlangkah pembelajaran PAI yng dilakukan sebagai berikut:

Berdasarkan hasil wawancara dengan guru 1 selaku guru PAI di SMP Negeri 1 Ngoro yang menyatakan bahwa :

"langkah-langkah pembelajaran PAI dalam mencegah bahaya radikalisme yang saya lakukan adalah saya selalu mengaitkan materi yang sedang dipelajari dengan pengalaman dalam kehidupan nyata. Misalnya pada bab toleransi jika dikaitkan langsung dalam kehidupan maka akan mudah dipahami oleh siswa. Jika kita bersatu maka pekerjaan seberat apapun akan menjadi ringan, begitu juga dengan sebaliknya pekerjaan yang mudah namun jika dikerjakan dengan adanya pertengkaran akan menjadi berat. Dengan mengaitkan materi dengan kehidupan masyarakat akan mudah dimengerti oleh siswa".

Hal yang sama disampaikan oleh guru 2 selaku guru PAI juga yang menyatakan bahwa :

"langkah-langkah pembelajaran yang saya lakukan sebenarnya sama seperti guru yang lain, Cuma bedanya kalau saya sebelum pembelajaran di mulai saya selalu mensosialisasikan bahayanya kekerasan terutama bagi kalangan remaja, bahayanya tawuran yang disebabkan karena tidak adanya toleransi dan juga tidak adanya sikap saling menghargai antara teman yang satu dengan teman yang lain terutama dengan yang berbeda agama. Dengan ini diharapkan siswa dapat menjaga hubungan baik antara teman baik sesama agama maupun beda agama“.

Pendapat lain dikemukakan oleh guru 3 selaku waka kurikulum yang menyatakan bahwa :

"Langkah-langkah pembelajaran PAI yang dilakukan di SMP Negeri 1 Ngoro ini sama seperti langkah-langkah pembelajaran pada umumya, yaitu sesuai dengan yang sudah ditulis di RPP, akan tetapi kalau langkah-langkah pembelajaran PAI dalam mencegah radikalisme ini saya lakukan dengan cara menceritakan tujuan awal masuknya agama Islam yaitu untuk rahmatan lil'alamin yaitu untuk kemaslahatan umat. Oleh Karena itu Allah tidak suka orang yang bersikap kasar dan suka memaksakan kehendaknya. Dengan ini diharapkan siswa memiliki rasa persaudaraan dan persatuan dan menolak adanya radikalisme".

Berdasarkan dari wawancara dan observasi yang dilakukan oleh peneliti diatas maka dapat disimpulkan bahwa langkah-langkah pembelajaran PAI dalam mencegah radikalisme yang dilakukan di SMP 
Negeri 1 Ngoro yaitu melalui tahap perencanaan dengan memberikan sosialisasi tentang radikalisme dan bahaya radikalisme terutama dikalangan remaja yang dikaitkan dengan materi PAI dan juga pentingnya bertoleransi terutama dilingkungan sekolah. Tahap pelaksanaan dengan terealisasinya sikap toleransi antar teman yang beda agama. Yang ketiga tahap evaluasi dengan menilai perilaku sikap siswa setelah dilakukan sosialisasi bahaya radikalisme dan pentingnya bertoleransi.

2. Strategi pembelajaran PAI dalam mencegah radikalisme di SMP Negeri 1 Ngoro

Radikalisme merupakan persoalan yang sangat besar tidak hanya di Indonesia saja melainkan di seluruh Indonesia, terutama bagi kalangan remaja. Mengapa demikian, karena remaja memiliki tingkat emosi yang masih sangat labil dan mudah untuk dipengaruhi. Mereka lebih mendahulukan emosi dari pada akal mereka, oleh karena itu mereka lebih mudah terpengaruh oleh hal-hal yang ekstrim tanpa terkecuali paham radikalisme. Untuk mencegah radikalisme ini di SMP Negeri 1 Ngoro melakukan beberapa cara, salah satunya melalui pembelajaran PAI.

Melalui pembelajaran PAI ini diharapkan dapat menacegah radikalisme yang ada di Indonesia yaitu dengan pendidikan yang dilakukan di sekolah umum, maupun madrasah. Dengan kata lain bahwa penyebab terjadinya berbagai gerakan yang merugikan masyarakat tersebut amat kompleks, dan karenanya cara menanggulanginya juga membutuhkan keterlibatan dari semua pihak. Selanjutnya berbagai hasil penelitian barubaru ini menunjukkan bahwa diantara yang terlibat dalam gerakan-gerakan tersebut adalah guru agama dan para siswa sekolah umum dan madrasah, bahkan juga dalam jumlah yang kecil dari tamatan pondok pesantren dan perguruan tinggi agama Islam.

Menurut wawancara dan pengamatan secara langsung yang dilakukan oleh peneliti, maka strategi pembelajaran PAI dalam mencegah radikalisme di SMP Negeri 1 Ngoro ini dilakukan dengan dua cara yaitu :

\section{a. Strategi pembelajaran PAI yang dilakukan di dalam kelas}

Strategi pembelajaran PAI di dalam kelas ini yaitu yang sesuai dengan kurikulum dari Kemenag, yang terdiri dari komponen-komponen strategi pembelajaran sebagai berikut :

\section{1) Tujuan Pembelajaran}

Tujuan merupakan aspek terpenting dalam pembelajaran. Adanya tujuan dapat memberikan arah kepada elemen pendidikan untuk mencapai hasil yang diinginkan, baik berkaitan dengan peserta didik atau pun visi dan misi lembaga pendidikan. 
Tujuan pembelajaran pada umumnya adalah untuk membentuk siswa yang berkarakter, beriman dan bertaqwa kepada Tuhan, serta memiliki sikap disiplin, memiliki keterampilan, kreativitas, dan mampu mengamalkan ilmunya dalam kehidupan sehari-hari, bermasyarakat dan bernegara serta berakhlaqul karimah yang sesuai dengan ajaran agama Islam. Salah satu cara yang digunakan untuk mewujudkan tujuan pembelajaran ini adalah dengan cara melakukan pembiasaan-pembiasaan yang dapat membentuk pribadi siswa, baik dalam hal pembiasaan keagamaan maupun pembiasaan yang berkaitan dengan toleransi antar beragama, mengapa demikian karena di SMP Negeri 1 Ngoro ini siswanya tidak hanya beragama Islam saja melainkan ada yang Kristen dan hindu juga. Ini secara tidak langsung juga dapat menumbuhkan sikap toleransi dan menghargai antar pemeluk agama.

Pernyataan ini sesuai dengan pendapat yang disampaikan oleh Bapak kepala sekolah SMP Negeri 1 Ngoro yang menyatakan bahwa :

"Tujuan dari pembelajaran yang kami lakukan disini pada dasarnya sesuai dengan visi dan misi dari SMP Negeri 1 Ngoro dan juga untuk membentuk siswa yang berkarakter, tidak hanya pada perilakunya terhadap orang lain akan tetapi juga pada bagaimana cara atau apa yang harus dilakukan jika ada sesuatu hal yang tidak baik disekitarnya, dan juga membentengi peserta didik dengan bekal ilmu agama dan juga penanaman nilai-nilai pancasila”.

Pendapat lain disampaikan oleh guru 1 selaku guru PAI, yang menyatakan bahwa :

"Tujuan pembelajaran PAI disini selain untuk menanamkan nilai-nilai agama kepada peserta didik juga untuk memperdalam pengetahuan tentang agama, apalagi di tingkat sekolah menengah pertama ini yang tingkat pemahaman agamanya masih sangat kurang terutama tentang pemahaman mana hal yang baik dan mana hal yang buruk. Melalui pembelajaran PAI ini diharapkan siswa dapat membedakan mana yang baik dan boleh dilakukan dan mana yang tidak boleh dilakukan. Dan melalui pembelajaran PAI disini guru juga menyingungkan tentang radikalisme dan bahayanya, dengan demikian diharapkan siswa jangan sampai terjerumus kearah radikalisme".

Berdasarkan pengamatan yang dilakukan peneliti di SMP Negeri 1 Ngoro tujuan dari pembelajaran yang dilakukan disini 
disesuaikan dengan visi dan misi sekolah. yaitu pembentukan sikap, pengetahuan, dan kreatifitas yang tinggi pada peserta didik. Tujuan tersebut dijadikan sebagai langkah awal dalam pencegahan paham radikalisme agama pada peserta didik melalui pembelajaran.

Pembentukan sikap menjadi salah satu tujuan yang harus dicapai peserta didik, karena bersikap yang baik dapat menjauhkan peserta didik dari sifat-sifat yang dapat mengarah kepada tindakan radikal. Aspek pengetahuan bertujuan agar peserta didik tidak hanya bersikap, tetapi juga mengatahui dasar dalam berperilaku dan bertindak. Selain itu, peserta didik tidak terpengaruh oleh pemahaman yang kolot dan keras. Sehingga paham radikalisme dapat diminimalisir sedini mungkin.

\section{2) Media Pembelajaran}

Media merupakan salah satu hal yang sangat penting dalam penyampaian strategi pembelajaran PAI terutama dalam hal mencegah radikalisme. Karena melalui media ini peserta didik dapat menerima pesan yang disampaikan guru dengan sempurna.

Sesuai dengan pendapat yang dikemukakan oleh wakil kepala sekolah terkait dengan penyediaan media pembelajaran yaitu :

"Media pembelajaran yang dilakukan untuk mencegah radikalisme adalah dengan menceritakan kisah teladan Nabi yang berdakwah dan mengajak pada kebaikan dengan cara yang baik tanpa adanya kekerasan. Disini melalui proyektor yang sudah disediakan guru bisa memanfaatkannya untuk memutarkan video tentang kisah tersebut. Dan diharapkan setelah siswa mengetahuinya secara langsung siswa lebih mudah untuk memahami mana sikap yang seharusnya dilakukan dan mana yang tidak".

Pendapat yang sama juga disampaikan oleh salah satu guru PAI yang menyatakan bahwa :

"Dalam proses pembelajaran disini selain menyediakan buku materi juga menggunakan pembelajaran dalam bentuk pengalaman dalam kehidupan sehari-hari. Karna kita bisa hidup lebih baik karena kita belajar dari pengalaman sebelumnya. Nah dari sini bisa diambil tentang sejarah kemerdekaan Indonesia yang walaupun tidak ada hubungannya dengan PAI tetapi ada hubu yang bisa mencegah adanya radikalisme". 
Berdasarkan dari hasil observasi dan wawancara yang dilakukan oleh peneliti di SMP Negeri 1 Ngoro ini media pembelajaran PAI yang digunakan untuk mencegah radikalisme adalah salah satunya dengan menceritakan dan menampilkan kisah keteladana nabi dalam berdakwah atau mengajak kebaikan dengan cara yang baik tanpa adanya kekerasan. Melalui pembelajaran ini diharapkan siswa bisa meniru perilaku yang baik yang dilakukan oleh nabi.

\section{3) Metode Pembelajaran}

Metode pembelajaran yang sudah digunakan di SMP Negeri 1 Ngoro diantaranya adalah metode ceramah, tanya jawab, diskusi, kisah, keteladanan, dan lain sebagainya. Dari sekian banyak metode pembelajaran yang ada yang sering digunakan oleh guru adalah metode ceramah, karena metode ini dianggap lebih mudah dan tidak membutuhkan banyak persiapan. Cara ini memang kadang membosankan, maka dalam pelaksanaannya membutuhkan keterampilan tertentu agar dapat menarik peserta didik. Meskipun demikian, metode ceramah sangat penting dengan tujuan agar peserta didik mendapat informasi tentang suatu persoalan. Selain tidak membutuhkan waktu yang lama, metode ini juga dapat membuat suasana kelas tenang karena aktivitas peserta didik sama.

Metode lain yang sering digunakan guru PAI dalam upaya menangkal radikalisme adalah dengan menggunakan metode keteladanan, kisah, pembiasaan dan pembinaan.

Pernyataan ini didukung oleh guru 1 selaku guru PAI yang menyatakan bahwa :

"Metode pembelajaran dalam mencegah adanya radikalisme ini melalui pemberian pemahaman kepada siswa tentang bahaya radikalisme dan akibat yang ditimbulkan dari adanya radikalisme itu sendiri. Dengan adanya pemahaman seperti ini diharapkan siswa dapat membentengi dirinya sendiri agar jangan sampai terpengaruh oleh paham radikalisme. Selain itu juga perlu menanamkan pentingnya sikap toleransi antar pemeluk agama agar tercipta kehidupan yang rukun dan damai terutama di lingkungan sekolah".

Pendapat lain disampaikan oleh guru 2 yang mengatakan bahwa:

"Guru yang baik adalah yang pandai dalam pemilihan metode pembelajaran yang digunakan, karena dengan metode yang tepat maka materi yang disampaikan kepada peserta didik akan mudah mereka fahami, dan juga dengan metode yang tepat tidak akan 
menimbulkan kebosanan atau kejenuhan dalam proses pembelajaran. Jadi metode merupakan hal yang penting dalam proses pembelajaran".

Menurut guru 3 selaku guru PAI 2 di SMP Negeri 1 Ngoro menyatakan bahwa :

"Strategi pembelajaran PAI dalam mencegah radikalisme yang kami lakukan disini adalah guru sering mengaitkan bahaya radikalisme ke dalam materi pembelajaran. Misalnya pada materi yang berkaitan dengan sejarah dakwah nabi Muhammad SAW yang selalu mengedepakan akhlakul karimah. Kemuliaan akhlak nabi ini yang harusnya menjadi contoh bagi umat Islam termasuk peserta didik. Guru PAI juga harus menjelaskan bahwa kekerasan bukanlah hal yang baik melainkan sesuatu yang sangat dilarang dan dibenci oleh agama karena menyakiti saudaranya sendiri. Selain menceritakan kisah nabi Muhammad SAW, kami juga menceritakan kisah-kisah keteladanan yang lain, kisah berdirinya agama Islam, kisah sejarah kemerdekaan Indonesia. Walaupun tidak ada hubungannya tetapi kami selalu menyampaikannya dengan tujuan untuk menanamkan cinta terhadap tanah air dan agama".

Berdasarkan observasi dan wawancara yang dilakukan peneliti maka dapat ditarik kesimpulan bahwa metode pembelajaran yang digunakan untuk mencegah radikalisme disini yaitu memberikan pemahaman kepada siswa tentang bahaya radikalisme dan akibat yang ditimbulkan dari radikalisme itu sendiri.

\section{4) Evaluasi Pembelajaran}

Evaluasi merupakan tahap akhir dalam sebuah pembelajaran. Adanya evaluasi dapat mengetahui keefektifan suatu pembelajaran, sehingga dapat dijadikan sebagai feed back bagi guru dalam memperbaiki dan menyempurnakan kegiatan pembelajaran. Adanya evaluasi juga bisa digunakan untuk mengetahui keberhasilan peserta didik dalam mencapai tujuan yang telah ditentukan, selain itu juga untuk mengetahui pemahaman siswa terhadap materi yang disampaikan.

Teknik evaluasi pada umunya yaitu menggunakan tes tulis, dan non tulis. Evaluasi disini dilakukan dengan cara menilai sikap siswa setelah diberikan pengarahan tentang radikalisme dan 
bahanya apakah ada perubahan terhadap sikap siswa, apakah lebih baik atau malah menjadi jelek.

Pendapat ini juga disampaikan oleh satu satu guru PAI yang menyatakan bahwa :

"Evaluasi pembelajaran pada umunya yang dilakukan disini adalah menggunakan dua tes yaitu tes tulis dan juga non tulis. Akan tetapi dalam evaluasi tentang strategi mencegah adanya radikalisme makayang dinilai adalah sikap siswa terutama dalam bergaul baik kepada teman sesama muslim maupun non muslim. Serta sikap siswa terhadap perbuatan yang mengajak kearah radikalisme".

Pendapat yang sama juga dikemukakan oleh salah satu siswa yang mengatakan bahwa :

"evaluasi disini rata-rata menggunkan tes tulis, tapi ada juga yang menggunakan non tulis seperi hafalan dan juga praktek. Dalam evaluasi ini menggunkan tes non tulis yaitu menggunakan penilaian terhadap sikap dan akhlak siswa".

Berdasarkan observasi dan wawancara yang dilakukan peneliti maka dapat disimpulkan bahwa evaluasi pembelajan dalam mencegah radikalisne adalah dengan menilai sikap dan perilaku siswa setelah mendapat pengarahan tentang radikalisme dan bahanya terutama bagi kalangan remaja.

\section{b. Strategi Mencegah Radikalisme Yang Dilakukan Di Luar Kelas}

Strategi pembelajaran PAI selain dilakukan pembelajaran didalam kelas yang sesuai dengan kurikulum yang ada, juga dilakukan pembelajaran diluar kelas, yaitu seperti ekstrakulikuler, sekaligus pembiasaan yang berbasis PAI, misalnya mulog keagamaan. Di SMP Negeri 1 Ngoro juga dilakukan penanaman nilai-nilai Pancasila, misalnya pada pembiasaan sebelum memulai pembelajaran terlebih dahulu menyanyikan lagu Indonesia raya kemudian membaca pancasila secara bersama-sama yang dipimpin oleh guru yang mengajar pada jam pertama. Ini dilakukan setelah sebelumnya dilakukan kegiatan pembacaan asmaul khusnah dan al-Quran, kegiatan ini memang sengaja dilakukan setiap hari sebagai kegiatan pembiasaan. Dan kegiatan ini dilakukan beriringan dengan tujuan untuk menyeimbangkan antara penanaman nilai keagaaman dan juga pancasila. Ini juga merupakan salah satu kiat yang dilakukan dalam menangkal bahaya radikalisme.

Ungkapan ini juga sesuai dengan pernyataan guru 1 selaku guru PAI, yang mengatakan bahwa : 
"Strategi pembelajaran PAI di SMP Negeri 1 Ngoro ini salah satunya dilakukan diluar jam sekolah, yaitu salah satunya dengan cara melakukan pendekatan kepada siswa. Dengan memberikan pengarahan tentang radikalisme tidak hanya pada siswa melainkan pada wali murid juga. Ini bertujuan untuk memberikan pengawasan terhadap siswa baik di lingkungan sekolah maupun dirumah".

Menurut guru 2 selaku wakil kepala sekolah menyatakan bahwa : "Salah satu strategi yang dilakukan dalam mencegah radikalisme di luar kelas adalah menjalin komunikasi yang baik diantara warga sekolah. Misalnya guru dengan murid, murid dengan murid, dan juga guru dan wali murid. Dengan demikian komunikasi antara guru dan orang tua akan terjaga, sehingga jika ada indikasi terkait radikalisme akan mudah diatasi. Selain itu, strategi pembelajaran PAI yang lain adalah melalui pelaksanaan pembiasaan, sebab menurut keyakinan kami jika pembiasaan itu dilakukan sesuai dengan ketentuan, maka paham atau unsur radikalisme tidak akan muncul, karena anak-anak telah menyadari bahwa dengan melakukan pembiasaan seperti berjabatan tangan saat masuk gerbang sekolah, kemudian membaca asmaul khusnah, mengaji al-Quran, kerja bakti kebersihan lingkungan sekolah, senam bersama, serta pendidikan budi pekerti yang inklut didalam mapel PAI dan PPKN, dapat menekan radikalisme".

Pendapat lain dikemukakan oleh guru 3, selaku waka kesiswaan yang menyatakan bahwa :

"strategi dalam mencegah terjadinya radikalisme yang dilakukan di luar kelas salah satu dengan cara pada setiap kegiatan apaun yang dilakukan yang berhubungan dengan sekolah akan diselipi dengan arahan dan motivasi untuk selalu menjunjung tinggi rasa persaudraan dan persatuan, toleransi dan juga rasa saling menghormati antara teman yang satu dengan yang lainnya".

Pendapat yang sama seperti yang diungkapkan oleh guru 1, ini juga di ungkapkan oleh siswa 1 selaku murid di SMP Negeri 1 Ngoro ini menyatakan bahwa :

"Strategi pembelajaran PAI yang dilakukan di luar kelas dengan cara menanamkan nilai cinta terhadap tanah air melalui kegiatan ekstra kepramukaan, penanaman nilai agama melalui kegiatan mulog keagamaan, penanaman nilai cinta terhadap diri sendiri melalui kegiatan senam bersama, dan juga kegiatan-kegiatan lain yang bernilai positif". 
Berdasarkan hasil dari wawancara dan observasi di atas yang dilakukan oleh peneliti, maka strategi pembelajaran PAI dalam menangkal radikalisme di SMP Negeri 1 Ngoro ini ada 2 cara, yaitu pertama melalui pembelajaran PAI didalam kelas dan yang kedua melalui pembelajaran diluar kelas. Adapun yang dilakukan di dalam kelas adalah seperti pembelajaran pada umunya sedangkan pendekatan pada siswa ini yang termasuk dalam pembelajaran di luar kelas, sekaligus menjalin komunikasi yang baik diantara warga sekolah.

\section{B. Diskusi Hasil Penelitian}

\section{Temuan Peneliti}

Setelah melakukan wawancara dengan berbagai sumber menggunakan instrumen penelitian, maka peneliti menemukan data bahwa implementasi pembelajaran PAI yang dilakukan di SMP Negeri 1 Ngoro dalam menangkal radikalisme adalah sebagai berikut :

\section{a. Langkah-langkah pembelajaran PAI dalam mencegah radikalisme di SMP Negeri 1 Ngoro}

Langkah-langkah pembelajaran ini sangat penting agar pembelajaran yang dilakukan dapat berjalan dengan baik dan mencapai tujuan secara maksimal. Langkah-langkah pembelajaran ini sebagai berikut:

1) Tahap Pendahuluan

Guru memberikan sosialisasi tentang radikalisme dan bahayanya terutama bagi kalangan remaja, sekaligus memberikan pengarahan tentang pentingnya sikap toleransi antar sesama teman baik sesama muslim maupun non muslim terutama di lingkungan sekolah.

2) Tahap Pelaksanaan

Terlaksananya hubungan yang seimbang antara yang muslim dan non muslim sebagai perwujudan dari sikap toleransi, berkurangnya tingkat pertikaian antar siswa sebagai wujud dari pemahaman terhadap bahaya radikalisme.

3) Tahap Uji Kemampuan atau Evaluasi

Penilain terhadap sikap dan perilaku siswa sebagai perwujudan pemahaman terhadap bahaya radikalisme.

b. Strategi Pembelajaran PAI dalam Menangkal Radikalisme di SMP Negeri 1 Ngoro

1) Strategi pembelajaran PAI yang dilakukan di dalam kelas

Strategi pembelajaran yang dilakukan di dalam kelas ini merupakan pembelajaran yang sesuai dengan kurikulum yang ada 
yaitu kurikulum dari kemenag, yang terdiri dari komponenkomponen sebagai berikut: ${ }^{8}$

a) Tujuan Pembelajaran

Tujuan pembelajaran merupakan aspek terpenting dalam pembelajaran. Adanya tujuan dapat memberikan arah kepada elemen pendidikan untuk mencapai hasil yang diinginkan, agar peserta didik tidak hanya bersikap, tetapi juga mengatahui dasar dalam berperilaku dan bertindak. Selain itu, peserta didik tidak terpengaruh oleh pemahaman yang kolot dan keras. Sehingga paham radikalisme dapat diminimalisir sedini mungkin.

b) Media Pembelajaran

Media pembelajaran yang dilakukan salah satunya dengan menceritakan dan menampilkan kisah keteladanan nabi dalam berdakwah atau mengajak kebaikan dengan cara yang baik tanpa adanya kekerasan. Melalui pembelajaran ini diharapkan siswa bisa meniru perilaku yang baik yang dilakukan oleh nabi.

c) Metode Pembelajaran

Metode pembelajaran dalam mencegah adanya radikalisme ini melalui pemberian pemahaman kepada siswa tentang bahaya radikalisme dan akibat yang ditimbulkan dari adanya radikalisme itu sendiri. Dengan adanya pemahaman seperti ini diharapkan siswa dapat membentengi dirinya sendiri agar jangan sampai terpengaruh oleh paham radikalis.

d) Evaluasi Pembelajaran

Evaluasi pembelajaran dalam mencegah radikalisne adalah dengan menilai sikap dan perilaku siswa setelah mendapat pengarahan tentang radikalisme dan bahanya terutama bagi kalangan remaja. ${ }^{9}$

2) Pembelajaran PAI yang dilakukan di luar kelas dalam menangkal radikalisme

Pembelajaran PAI tidak hanya dilakukan didalam kelas saja melainkan bisa dilakukan diluar kelas melalui kegiatan-kegiatan ekstrakulikuler yang berbasis PAI. Dilakukan pula pendekatan kepada siswa untuk mengetahui permasalahn yang sedang dihadapi oleh peserta didik. Selain itu juga dijalin hubungan komunikasi yang

8 Abdulloh, Pengembangan Kurikulum Teori dan Praktek, (Yogyakarta, Ar-ruzz Media, 2010), 51.

9 Rusman, Manajemen Kurikulum,(Jakarta, Rajawali Pers, 2008), 114-118. 
baik diantara warga sekolah. Misalnya guru dengan murid, murid dengan murid, sekolah dengan walimurid, serta pihak sekolah dengan masyarakat.

Selain itu, strategi pembelajaran PAI yang lain adalah melalui pelaksanaan pembiasaan, sebab menurut keyakinan kami jika pembiasaan itu dilakukan sesuai dengan ketentuan, maka paham atau unsur radikalisme tidak akan muncul, karena anak-anak telah menyadari bahwa dengan melakukan pembiasaan seperti berjabatan tangan saat masuk gerbang sekolah, kemudian membaca asmaul khusnah, mengaji al-Quran, kerja bakti kebersihan lingkungan sekolah, senam bersama, serta pendidikan budi pekerti yang inklut didalam mapel PAI dan PPKN, dapat menekan radikalisme”.

\section{Analisis Data}

Data yang diperoleh yang sudah dipaparkan akan dianalisis oleh peneliti sesuai dengan hasil penelitian yang mengacu pada beberapa fokus penelitian diatas. Analisis peneliti tentang implementasi pembelajaran PAI dalam menangkal radikalisme di SMP Negeri 1 Ngoro sebagai berikut :

a. Langkah-langkah Pembelajaran PAI dalam mencegah radikalisme di SMP Negeri 1 Ngoro

Langkah-langkah pembelajaran PAI ini guru memberikan sosialisasi tentang radikalisme dan bahayanya terutama bagi kalangan remaja yang dikaitkan dengan materi PAI, dan juga guru memberikan pengertian pentingnya sikap toleransi antar pemeluk agama lain terutama dilingkungan sekolah.

Tahap pelaksanaan dengan terealisasinya sikap toleransi antar teman disekolah terutama yang beda agama bahkan dalam waktu pembelajaran PAI sekalipun, dan juga setelah adanya sosialisasi tentang radikalisme siswa lebih jarang berselisih pendapat maupun bertengkar dengan sesama teman.

Tahap evaluasi, yaitu dengan menilai perilaku sikap siswa setelah dilakukan sosialisasi bahaya radikalisme dan pentingnya bertoleransi.

Hal ini sesuai dengan teori yang dikemukakan oleh Hamzah B. Uno dalam bukunya yang berjudul "Model Pembelajaran Menciptakan Proses Belajar Mengajar yang Kreatif' mengatakan bahwa pembelajaran dapat diartikan sebagai suatu proses interaksi antara peserta didik dan pendidik dalam suatu lingkungan belajar 
untuk mencapai tujuan pembelajaran. ${ }^{10}$ Dapat di artikan sebagai interaksi antara guru dengan murid dalam lingkungan belajar baik di dalam kelas maupun diluar kelas untuk mencapai tujuan pembelajaran.

Langkah-langkah pembelajaran yang dilakukan sesuai dengan teori yang dikemukakan oleh Mulyono (2012) dalam bukunya yang berjudul "Strategi Pembelajaran (Menuju Efektivitas Pembelajaran di Abad Global" mengatakan bahwa ada tiga pokok tahap dalam pembelajaran, yakni tahap permulaan (praintruksional), tahap pengajaran (intruksional), tahap penilaian, dan tahap tindak lanjut : (1) Tahapan Permulaan (Prainstruksional), Tahap prainstruksional adalah tahapan yang ditempuh guru pada saat ia memulai proses belajar mengajar. (2). Tahapan Pengajaran (Instruksional) adalah tahap pengajaran atau tahap inti, yakni tahapan memberikan bahan pelajaran yang telah disusun guru sebelumnya. (3). Tahap Evaluasi dan Tindak Lanjut tahap evaluasi atau penilaian dan tindak lanjut dalam kegitan pembelajaran. Tujuan tahapan ini untuk mengetahui tingkat keberhasilan dari tahapan kedua (instruksional). ${ }^{11}$

b. Strategi Pembelajaran PAI dalam mencegah radikalisme di SMP Negeri 1 Ngoro

Radikalisme merupakan persoalan yang sangat besar tidak hanya di Indonesia saja melainkan di seluruh dunia, permasalahan ini sangatlah kompleks sehingga penanganannyapun haruslah melibatkan banyak kalangan. Nah di SMP Negeri 1 Ngoro ini cara yang digunakan dalam menangkal radikalisme dilakukan beberapa cara, salah satunya melalui pembelajaran PAI.

Pembelajaran PAI ini diharapkan dapat mencegah radikalisme tidak hanya di SMP Negeri 1 Ngoro saja melainkan di sekolah-sekolah umum lainnya maupun sekolah madrasah. Hal ini juga didukung oleh teori yang dikemukan oleh Abuddin Nata yaitu "peningkatan radikalisme keagamaan banyak berakar pada kenyataan kian merebaknya berbagai penafsiran, pemahaman, aliran, bahkan sekte di dalam (intra) satu agama tertentu. Dengan kata lain bahwa penyebab terjadinya berbagai gerakan yang

${ }^{10}$ Hamzah B. Uno, Model Pembelajaran Menciptakan Proses Belajar Mengajar yang Kreatif, (Jakarta: Bumi Aksara, 2009), 130-131.

${ }^{11}$ Mulyono. Strategi Pembelajaran (Menuju Efektivitas Pembelajaran di Abad Global), (Malang: UIN-Maliki Press. 2012), 29-30. 
merugikan masyarakat tersebut amat kompleks, dan karenanya cara menanggulanginya juga membutuhkan keterlibatan dari semua pihak. ${ }^{12}$

Selanjutnya berbagai hasil penelitian baru-baru ini menunjukkan bahwa diantara yang terlibat dalam gerakangerakan tersebut adalah guru agama dan para siswa sekolah umum dan madrasah, bahkan juga dalam jumlah yang kecil dari tamatan pondok pesantren dan perguruan tinggi agama Islam. Sejalan dengan kenyataan di atas, maka diupayakan cara-cara mengatasi masalah tersebut secara efektif, mendasar dan berjangka panjang yaitu dengan cara: memberikan pemahaman kepada masyarakat tentang wawasan berbagai konsep demokrasi, persamaan dan kebebasan secara komprehensif dan mendasar melalaui pendidikan agama Islam yang berlangsung di Sekolah Umum, Madrasah maupun Perguruan Tinggi Umum dan Agama”. Seperti yang dilakukan di SMP Negeri 1 Ngoro, disini juga menerapkan implementasi pembelajaran PAI dalam menangkal radikalisme.

Strategi pembelajaran PAI dalam menangkal radikalisme yang dilakukan di SMP Negeri 1 Ngoro melalui dua cara yaitu pembelajaran di dalam kelas dan juga dilakukan pembelajaran di luar kelas. Pembelajaran yang dilakukan di dalam kelas terdiri dari komponen-komponen yaitu tujuan pembelajaran, media pembelajaran, metode pembelajaran dan evaluasi pembelajaran. Ini sesuai dengan teori Mulyono (2012) dalam bukunya yang berjudul "Strategi Pembelajaran (Menuju Efektivitas Pembelajaran di Abad Global" yang mengatakan bahwa strategi adalah ilmu dan kiat dalam memanfaatkan segala sumber yang dimiliki yang dapat digunakan untuk mencapai tujuan yang telah ditetapkan. $^{13}$

Strategi pembelajaran terkandung makna perencanaan, artinya bahwa strategi pada dasarnya masih bersifat konseptual tentang keputusan-keputusan yang akan diambil dalam suatu pelaksaan pembelajaran. Ada empat unsur strategi yang diterapkan dalam konteks pembelajaran, keempat unsur tersebut adalah: Menetapkan spesifikasi dan kualifikasi tujuan pembelajaran, Mempertimbangkan dan memilih media pembelajaran yang dipandang paling efektif, Mempertimbangkan

${ }^{12}$ Abuddin Nata, Sosiologi Pendidikan Islam. (Jakarta: PT Raja Grafindo Persada. 2014).

${ }^{13}$ Mulyono, Strategi Pembelajaran, 7. 
dan menetapkan metode pembelajaran., Menetapkan kriteria dan ukuran baku keberhasilan.

Adapun strategi yang dilakukan di SMP Negeri 1 Ngoro melalui dua cara ini menggunakan strategi pembelajaran tidak langsung. Hal ini sesuai dengan pendapat Abdul Majid dalam bukunya yang berjudul "Belajar dan Pembelajaran " yang membagi macam-macam strategi pembelajaran menjadi tujuh.

\section{SIMPULAN}

Langkah-langkah pembelajaran PAI dalam mencegah radikalisme di SMP Negeri 1 Ngoro : a). Tahap pendahuluan yaitu guru memberikan sosialisasi tentang radikalisme dan bahayanya terutama bagi kalangan remaja yang dikaitkan dengan materi PAI. b). Tahap pelaksanaan, dengan terealisasinya sikap toleransi siswa lebih jarang berselisih pendapat maupun bertengkar dengan sesama teman. c). Tahap evaluasi, yaitu dengan menilai perilaku sikap siswa setelah dilakukan sosialisasi bahaya radikalisme dan pentingnya bertoleransi.

Stategi pembelajaran PAI dalam mencegah radikalisme yang di lakukan di SMP Negeri 1 Ngoro menggunakan strategi pembelajaran tidak langsung, yaitu strategi yang menuntut siswa untuk aktif dalam pembelajaran. Siswa belajar dengan membangun pengetahuan mereka sendiri melalui pengalaman dengan bantuan guru sebagai fasilitator. Strategi ini dilakukan melalui dua cara yaitu : a). Strategi didalam kelas, dilakukan melalui tujuan pembelajaran, media pembelajaran, metode pembelajaran dan evaluasi pembelajaran. b). Strategi di luar kelas, ini dilakukan melalui pendekatan kepada peserta didik, dan menerapkan pembiasaan-pembiasaan yang positif.

\section{DAFTAR PUSTAKA}

Abdulloh. 2010. Pengembangan Kurikulum Teori dan Praktek. Yogyakarta: Arruzz Media.

Aniyah, Qurrotul dan Moch. Sya'roni Hasan, Kehidupan Pluralisme Dan Penangkalan Radikalisme (Studi Kasus Di Pondok Pesantren Al-Urwatul Wutsqo Jombang) Proceedings: International Conference on "Islam Nusantara, National Integrity, and World Peace" 2018.

Aqib, Z. 2002. Profesionalisme Dalam Pembelajaran. Surabaya: Cendekiawan, Desmita, 2009. Psikologi Perkembangan Peserta Didik : Panduan Bagi Orang Tua dan Guru dalam Memahami Psikologi Anak Usia SD,SMP,SMA. Bandung: Rosdakarya.

Emzir. 2014. Metodologi Penelitian Kualitatif Analisis Data. Jakarta: RajaGrafindo Persada,

Hasan, Musohihul. "Nilai-nilai Pendidikan Islam dalam Maulid Nabi Muhammad SAW." Al-Insyiroh: Jurnal Studi Keislaman 1.1 (2015): 180-213. 
Hasan, Moch. Sya'roni. 2019. Internalisasi Nilai Toleransi Beragama Di Masyarakat. Sidoarjo: Kanaka Media.

Mulyono. 2012. Strategi Pembelajaran (Menuju Efektivitas Pembelajaran di Abad Global), (Malang: UIN-Maliki Press.

Nata, Abuddin. 2014..Sosiologi Pendidikan Islam. Jakarta: PT Raja Grafindo Persada.

Nurdin, A. Fauzi. 2005. Islam dan Perubahan Sosial. Semarang: Reality Press.

Putra, M. Kholil Baita. "Eksistensi Sistem Pesantren Salafiyah Dalam Menghadapi Era Modern." Al-Insyiroh: Jurnal Studi Keislaman 1.1 (2015): 87-104

Rusman. 2008. Manajemen Kurikulum. Jakarta, Rajawali Pers.

Sugiyono. 2013. Metode Penelitian Pendidikan (Pendekatan Kuantitatif, Kualitatif, dan $R \& D)$. Bandung: Alfabeta.

Uno, Hamzah B. 2009. Model Pembelajaran Menciptakan Proses Belajar Mengajar yang Kreatif. Jakarta: Bumi Aksara. 